\title{
Prevalence of anaemia in preschool children in Karma Albalad area, Northern State, Sudan
}

\author{
M.D. Hussein ${ }^{1}$ and S. Mohamed ${ }^{2}$
}

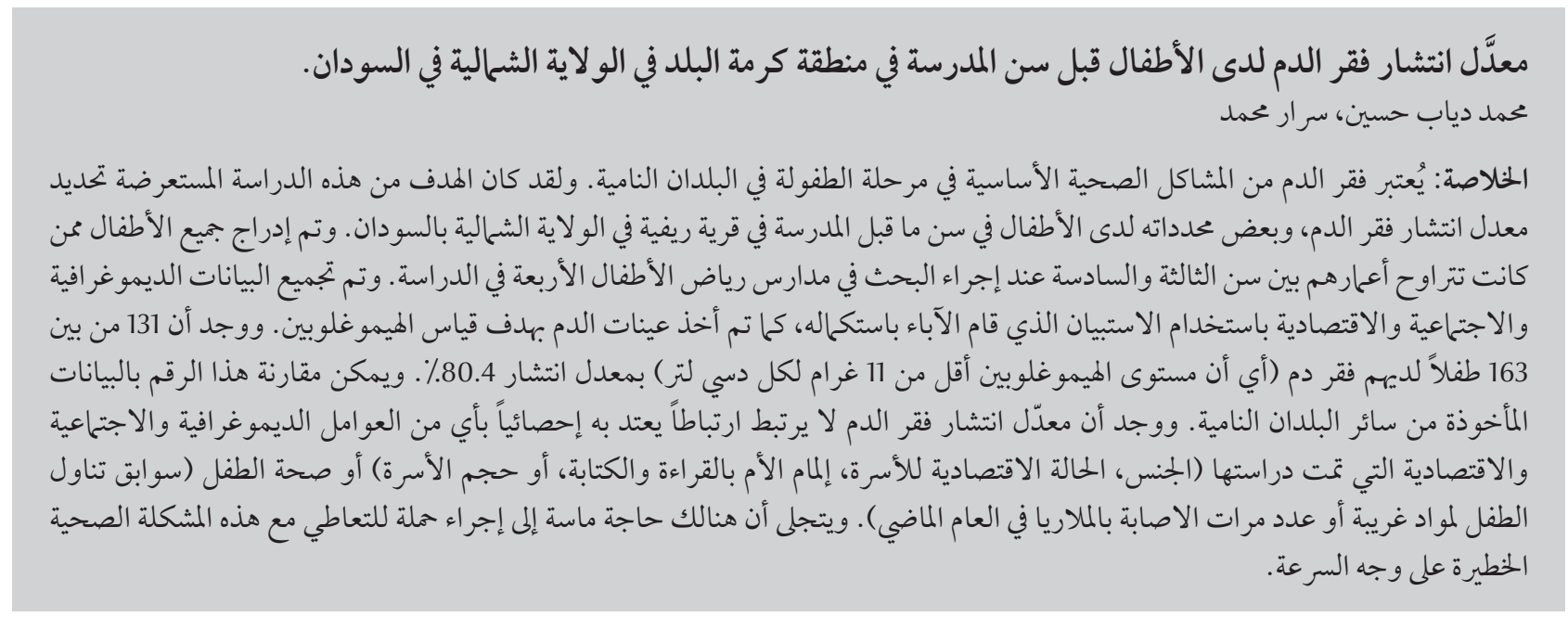

ABSTRACT Anaemia is a major childhood health problem in developing countries. The aim of this cross-sectional study was to determine the prevalence of anaemia, and some of its determinants, in preschool children in a rural village in the Northern State of Sudan. All children aged 3-6 years attending the 4 village kindergartens on the day of the study were enrolled. Demographic and socioeconomic data were collected using a questionnaire completed by parents, and blood samples were taken for haemoglobin measurement. Out of 163 children, $131 \mathrm{had}$ anaemia (haemoglobin level $<11 \mathrm{~g} / \mathrm{dL}$ ), a prevalence of $80.4 \%$. This figure is comparable to data from other developing countries. The prevalence of anaemia was not significantly associated with any of the studied demographic and socioeconomic factors (sex, economic status of the family, mother's literacy or family size) or health of the child (history of pica or number of attacks of malaria in the last year). A campaign to tackle this serious health issue is urgently needed.

Prévalence de l'anémie chez des enfants d'âge préscolaire dans la région de Karma Albalad dans I'État du Nord au Soudan

RÉSUMÉL'anémie chezl'enfant estune préoccupation desantépublique majeure dansles pays en développement. L'objectif de la présente étude transversale était de déterminer la prévalence de l'anémie ainsi que certains de ses déterminants chez des enfants d'âge préscolaire dans un village rural de l'État du Nord du Soudan. Tous les enfants âgés de trois à six ans fréquentant les quatre écoles maternelles du village le jour de l'étude ont participé. Les données démographiques et socioéconomiques ont été recueillies à l'aide d'un questionnaire rempli par les parents, et des échantillons de sang ont été prélevés pour le dosage du taux d’hémoglobine. Sur 163 enfants, 131 souffraient d'anémie (taux d’hémoglobine $<11 \mathrm{~g} / \mathrm{dl}$ ), une prévalence de $80,4 \%$. Ce chiffre est comparable aux données d'autres pays en développement. La prévalence de l'anémie n'était significativement associée à aucun des facteurs démographiques et socioéconomiques étudiés (sexe, statut socioéconomique de la famille, degré d'alphabétisme de la mère ou taille de la famille) ni à la santé de l'enfant (antécédents de syndrome de pica ou nombre d'épisodes de paludisme au cours de l'année précédente). Une campagne pour s'attaquer à ce problème de santé sérieux est nécessaire de toute urgence. 


\section{Introduction}

Anaemia is a major child health problem worldwide [1-3]. One-third of the world's population suffers from anaemia, notably over half of the children in developing countries [1]. Iron deficiency is the main cause of childhood anaemia; other causes include micronutrient deficiencies, haemoglobinopathies and infections such as malaria [4-9]. Children are more vulnerable to developing anaemia because they are rapidly growing and liable to infection. Moreover, micronutrients such as iron and folic acid are likely to be inadequate in children's diets if parents are not well informed $[2,9,10,11]$. Anaemia is not only one of the leading causes of childhood mortality and morbidity [12], it may also affect cognitive development and school performance $[13,14]$.

According to the World Health Organization (WHO), the prevalence of anaemia, defined as haemoglobin ( $\mathrm{Hb})$ level $<11 \mathrm{~g} / \mathrm{dL}$, among children aged under 5 years in Africa varies from $49 \%$ to $89 \%$ [1]. To our knowledge, few studies have investigated the prevalence of anaemia in Sudanese children [1,15-17] and there are no recent epidemiological studies. $\mathrm{Nev}$ ertheless it is likely that it continues to be a significant burden on health facilities in the country, as documented in a survey conducted in 2006, which estimated the prevalence of anaemia in Sudanese children under 5 years old as $84.9 \%[12,15]$. There have been changes in recent decades in the demography and socioeconomic status of the Sudanese community, both negative due to civil wars and natural disasters (flooding and desertification), as well as positive due to Sudan became an oil-producing country. We therefore undertook this epidemiological study to determine the prevalence of anaemia, and some of its determinants, in an area in the north of Sudan. This would help local health decision-makers to plan for prevention and comprehensive management of this important health problem $[2,3,11]$.

\section{Methods}

\section{Study area and population}

The current study was conducted in Karma Albalad, which is a village in the Northern State of Sudan. It is located on the east bank of the River Nile, 60 $\mathrm{km}$ north of Dongola (the capital of the region). The population of the Northern State of Sudan is 750000 according to the recent census, with the vast majority living in rural areas. About 10000 people live in Karma Albalad, 800 of them in the age group $1-5$ years according to Ministry of Health data from the expanded programme on immunization in Northern State [12]. Most of the residents of the village are farmers, while a few are labourers, employees or working abroad [18]. The educational facilities include 4 kindergartens, 5 mixed primary schools and 1 secondary school for girls. There is a health centre run by a medical assistant and a hospital with paediatric facilities in the nearby village of Alborgeig. We selected Karma Albalad as the study area because it is the biggest and most populous village in the Northern State. Furthermore, there are 4 kindergarten schools in this village while the other villages have only 1 or 2 .

Although preschool education is not mandatory in Sudan, it is strongly recommended by the Ministry of Education. All kindergartens in Karma Albalad are public, with admission free of charge for all children. The great majority of parents admit their children to these kindergartens as it is widely believed among the local community that kindergarten improves the academic and social performance in later school years. There are no available data on the number of preschool age children in the village. However, children attending kindergartens are fairly representative of the preschool age group as they account for about nearly $20 \%$ of the children aged $<5$ years in the village [12].

\section{Study design and sample}

This was a cross-sectional study. All children aged 3-6 years who attended the 4 kindergartens in Karma Albalad on the day of the study (8 January 2010) were included in the study group. Written consent was taken from the local authority as well as from the parents of children participating in the study. Illiterate parents gave verbal consent to the research team members in the presence of a witness.

\section{Data collection}

The study team included the first author, 2 medical officers, 2 nurses and 2 laboratory technicians. The team members received training by the first author on the study technique. The first author also trained the kindergarten teachers on how to fill the questionnaire. The research team trained parents on how to fill the questionnaire. The research team and the teachers assisted parents, especially illiterate ones, who had difficulty in completing the questionnaire. Some of the parents who were comfortable with filling the questionnaire after the training session did so at home and returned it later. Children whose parents refused to participate in the study or failed to fill the questionnaire were excluded.

\section{Questionnaire}

The questionnaire was designed by the 2 authors and was pilot-tested on a group of school-age children not attending kindergarten to anticipate any problems in phrasing or understanding of the questions by parents. It was in Arabic language, which is the 
language spoken by the local community. The questionnaire covered the demographic and socioeconomic status of the families. The first part of the questionnaire consisted of demographic information about the child (age, sex). The second part contained information about the parents (education, occupation, income). The third and main part of the questionnaire was on the health status of the child and the risk factors for anaemia including history of chronic diseases (asthma, diabetes, renal disease, tuberculosis), number of attacks of malaria in the last year and history of pica in the last 2 years. Frequent malaria attacks refers to having 4 or more malaria attacks in the last year. Education of parents was categorized as follows: illiterate, primary school, secondary school and post-secondary education. For income we adopted the Northern State local authority classification of families: poor (receiving government allowances) or not poor (not receiving government assistance).

\section{Laboratory methods}

A $2 \mathrm{~mL}$ blood sample was taken from all participating children. The $\mathrm{Hb}$ level was measured within 6 hours after collection using the HemoCue system and Drapkins reagents. In this study, anaemia was defined as $\mathrm{Hb}<11 \mathrm{~g} / \mathrm{dL}$. Mild anaemia was $\mathrm{Hb}<11>9.9 \mathrm{~g} / \mathrm{dL}$, moderate anaemia was $\mathrm{Hb} 7-9 \mathrm{~g} / \mathrm{dL}$, while severe anaemia was $\mathrm{Hb}<7 \mathrm{~g} / \mathrm{dL}$ $[1,2,9]$.

\section{Statistical analysis}

The data were entered and analysed using SPSS, version 17 . The difference between 2 proportions test was used to test statistical significance. It was considered significant when $P$-value $<0.05$.

Binary logistic regression test was used to determine risk factors associated with anaemia in the study population.

\section{Results}

Of the 189 children eligible for the study, 4 were excluded as the parents refused to participate and 13 failed to attend for testing. Questionnaires were distributed to the parents of 172 children, of whom 9 failed to fill and return the questionnaire. Questionnaire data and blood samples were therefore analysed for 163 children (94.8\% response rate).

Table 1 shows the characteristics of the study group. There were 82 girls and 81 boys. A majority of the children (43.0\%) were from large families ( $\geq$ 4 children), while the rest were from small families ( $<4$ children). Pica behaviour was reported in 17 children ( $10.4 \%$ of the study group). Fathers of $13.5 \%$ of the study children were illiterate while $7.4 \%$ had illiterate mothers. Fathers of $77.3 \%$ of children were farmers. A quarter of the studied children $(24.5 \%)$ were from poor families (receiving regular allowances from the social authority).

Out of 163 studied children, 131 had $\mathrm{Hb}$ levels below the cut-off for anaemia, a prevalence of $80.4 \%$. Anaemia was graded as mild in 81 (49.7\%), moderate in $47(28.8 \%)$ and severe in $3(1.8 \%)$.

Table 2 shows that the prevalence of anaemia was not statistically significantly related to any of the studied demographic and socioeconomic factors (sex, economic status of the family, mother's literacy or family size) or health of the child (history of pica or number of attacks of malaria in the last year).

\section{Discussion}

Anaemia is a global health problem and is one of the major causes of childhood mortality and morbidity [1].As the epidemiological data on anaemia in Sudanese children are scarce [12], we decided to study the prevalence of anaemia in children as an important determinant of well-being.

In the present study the prevalence of anaemia among preschool children in Karma Albalad village was $80.4 \%$. This is consistent with the results of the household survey conducted in Sudan in 1994, which reported a prevalence of anaemia in preschool children in Sudan as 84.9\% [13]. This

Table 1 Characteristics of the study group of preschool children in Karma Albalad, Northern State, Sudan $(n=163)$

\begin{tabular}{lcc} 
Characteristic & No. & $\%$ \\
$\quad$ Male & 81 & 49.7 \\
$\quad$ Female & 82 & 50.3 \\
Family characteristics & & \\
$\quad$ Large family & 70 & 43.0 \\
Poor family & 40 & 24.5 \\
Illiterate mother & 12 & 7.4 \\
Health history & & \\
Frequent malaria attacks & 55 & 33.7 \\
History of pica & 17 & 10.4 \\
Asthma & 13 & 8.0 \\
$\quad$ Type 1 diabetes & 1 & 0.6 \\
Recurrent urinary tract infection & 1 & 0.6 \\
$\quad$ Tuberculosis & 0 & 0.0 \\
\hline
\end{tabular}




\begin{tabular}{|c|c|c|c|c|c|c|c|}
\hline \multirow[t]{2}{*}{ Risk factors } & \multicolumn{2}{|c|}{$\begin{array}{c}\text { Anaemic } \\
\mathrm{Hb}<11 \mathrm{~g} / \mathrm{dL} \\
(n=131)\end{array}$} & \multicolumn{2}{|c|}{$\begin{array}{l}\text { Not anaemic } \\
\mathrm{Hb} \geq 11 \mathrm{~g} / \mathrm{dL} \\
(n=32)\end{array}$} & \multirow[t]{2}{*}{ OR } & \multirow[t]{2}{*}{$95 \% \mathrm{Cl}$} & \multirow[t]{2}{*}{$P$-value } \\
\hline & No. & $\%$ & No. & $\%$ & & & \\
\hline \multicolumn{8}{|l|}{ Sex } \\
\hline Male & 63 & 48.1 & 18 & 56.3 & 1.19 & $0.54-2.60$ & 0.54 \\
\hline Female & 68 & 51.9 & 14 & 43.8 & 1.19 & $0.54-2.66$ & 0.54 \\
\hline \multicolumn{8}{|c|}{ Family characteristics } \\
\hline Large family & 58 & 44.3 & 12 & 37.5 & 0.78 & $0.30-1.76$ & 0.55 \\
\hline Poor family & 33 & 25.2 & 7 & 21.9 & 1.06 & $0.49-2.80$ & 0.90 \\
\hline Illiterate mother & 11 & 8.4 & 1 & 3.1 & 2.63 & $0.30-22.7$ & 0.38 \\
\hline \multicolumn{8}{|l|}{ Health history ${ }^{a}$} \\
\hline $\begin{array}{l}\text { Frequent malaria } \\
\text { attacks }\end{array}$ & 45 & 34.4 & 10 & 31.3 & 0.88 & $0.37-2.06$ & 0.37 \\
\hline Pica & 16 & 12.2 & 1 & 3.1 & 0.23 & $0.03-1.80$ & 0.16 \\
\hline
\end{tabular}

${ }^{a}$ Of the 13 children with asthma 6 had $\mathrm{Hb} \geq 11 \mathrm{~g} / \mathrm{dL}$ and $7 \mathrm{had} \mathrm{Hb}<11 \mathrm{~g} / \mathrm{dL}$. The 1 child with type 1 diabetes had normal Hb and the 1 child with recurrent urinary tract infection had low $\mathrm{Hb}<11 \mathrm{~g} / \mathrm{dL}$.

$H b=$ haemoglobin; $O R=$ odds ratio; $C I=$ confidence interval .

alarmingly high prevalence of anaemia is comparable with results from studies conducted in other developing countries such as India and Nigeria [19-22]. The situation, however, is very different from that in developed countries $[1,23]$. For instance, the prevalence of anaemia in children in the United States of America has been reported as only $16 \%$ [1]. It is well known that the prevalence of anaemia rises with increasing poverty [24-26]. The high prevalence of anaemia in this study is therefore not surprising as Sudan is one of the poorest countries in the world. The recent Sudan poverty assessment prepared by the World Bank and the Sudan government stated that overall $46.5 \%$ of the population was below the poverty line with a higher rate $(57.6 \%)$ among the rural population [27]. Other profiles present a detailed analysis of poverty, demographic, livelihood, education and employment in the country [28-30]. Our study was conducted in a rural area where the great majority of the parents were farmers with limited income and education.
People living in rural areas of Sudan constitute $86 \%$ of the population according to the 2008 census [29]. The rural community in Sudan is homogenous and the majority of people are from the same tribe, which explains the similarities in their social characteristics. When we analysed the possible risk factors associated with anaemia, such as parent's education, family size, family income and other socioeconomic indicators of poverty, none of these risks factors were statistically significantly associated with anaemia. This study was conducted in a rural village community where families are extended and share a similar culture; therefore the lifestyles of the people, especially eating habits, are expected to be relatively similar, despite differences in socioeconomic status. So, socioeconomic factors would not have as great an impact on children's nutrition as compared with urban communities. In contrast to our findings, Alawady et al. reported a high prevalence of anaemia among children with uneducated mothers in Kuwait [31]. In the USA too, parent's education was reported as a risk factor for the development of childhood anaemia [1].

Most of the children in this study were exposed to multiple attacks of malaria in the year prior to the date of the study. This is understandable as malaria is endemic in Sudan. However, recurrent attacks of malaria ( $\geq 4$ times per year) were not shown to be a risk factor for anaemia in this study. Malaria causes anaemia by subjecting red blood cells to haemolysis [6]. Severe malaria as well as the presence of glucose-6-phosphate dehydrogenase deficiency (G6PDD) are known risk factors for development of haemolysis associated anaemia [32]. Mild malaria, however, is not usually a cause of anaemia, and most of the children in the current study had mild anaemia. While G6PDD is common in the west of Sudan, it is not in the north. All these factors may possibly explain the finding that malaria was not associated with anaemia in this study.

Relatively small numbers of anaemic children in the current study were reported to have pica, which was not statistically different from the numbers of non-anaemic children. Pica is a social stigma; therefore a 
questionnaire-based study may not be the best way to obtain objective data on the prevalence of pica. This may be one of the limitations of the study. Other limitations include the relatively small study sample and the lack of a control group. Further investigations to determine the etiology of anaemia in these children were beyond the scope of this study. However, having more data as to the type and cause of anaemia would be informative. We recommend that a more comprehensive study on a wider scale would be helpful to validate our findings and to stimulate the authorities to address this important childhood health problem. Daily iron supplementation, for example, is a viable intervention to increase $\mathrm{Hb}$ levels [33]. A campaign to tackle this detrimental health issue is urgently needed.
Acknowledgements

Funding: This study was funded by Dongola Police Hospital and partly by the College of Medicine Research Center, Deanship of Scientific Research, King Saud University, Saudi Arabia. The authors would like to thank these two institutes for funding this work.

Competing interests: None declared.

\section{References}

1. De Benoist B et al. Worldwide prevalence of anaemia 19932005: WHO global database on anaemia. Geneva, World Health Organization, 2008.

2. McLean E et al. Worldwide prevalence of anaemia, WHO Vitamin and Mineral Nutrition Information System, 19932005. Public Health Nutrition, 2009, 12:444-454.

3. Galloway R. Anemia prevention and control: what works? Geneva, USAID/World Bank/PAHO-WHO/Micronutrient Initiative/FAO/UNICEF, 2003.

4. Zimmermann MB, Hurrell RF. Nutritional iron deficiency. Lancet, 2007, 370:511-520.

5. Magalhães RJ, Clements AC. Mapping the risk of anaemia in preschool-age children: the contribution of malnutrition, malaria, and helminth infections in West Africa. PLoS Medicine, 2011, 8:e1000438.

6. Ghosh K, Ghosh K. Pathogenesis of anemia in malaria: a concise review. Parasitology Research, 2007, 101:1463-1469.

7. Soares Magalhães RJ, Clements AC. Spatial heterogeneity of haemoglobin concentration in preschool-age children in sub-Saharan Africa. Bulletin of the World Health Organization, 2011, 89:459-468.

8. Giha $\mathrm{HA}$ et al. Severe malaria in an unstable setting: clinical and laboratory correlates of cerebral malaria and severe malarial anemia and a paradigm for a simplified severity scoring. European Journal of Clinical Microbiology and Infectious Diseases, 2009, 28:661-665.

9. Dallman PR, Yip R, Oski FA. Iron deficiency and related nutritional anemias. In: Nathan DG, Oski FA, eds. Hematology of infancy and childhood, 5th ed. Philadelphia, WB Saunders Company, 1999.

10. Iannotti LL et al. Iron supplementation in early childhood: health benefits and risks. American Journal of Clinical Nutrition, 2006, 84:1261-1276.

11. García-Casal MN et al. A program of nutritional education in schools reduced the prevalence of iron deficiency in students. Anemia, 2011, 2011:284050.

12. Annual statistical report 2009. Khartoum, Sudan, Federal Ministry of Health, 2010.

13. Baumgartner J et al. Effects of iron and n-3 fatty acid supplementation, alone and in combination, on cognition in school children: a randomized, double-blind, placebocontrolled intervention in South Africa. American Journal of Clinical Nutrition, 2012, 96:1327-1338.

14. De-Regil LM et al. Intermittent iron supplementation for improving nutrition and development in children under 12 years of age. Cochrane Database of Systematic Reviews, 2011, 7:CD009085.
15. Health multiple indicators cluster survey 2006. Khartoum, Sudan, Federal Ministry of Health, 2006.

16. Omer A et al. Studies on the anaemia of kwashiorkor and marasmus in the Sudan. Journal of Tropical Pediatrics and Environmental Child Health, 1973, 19:91-97.

17. Rekart ML, Plastino J, Carr C. Health status of teenage school boys in eastern Sudan. East African Medical Journal, 1985, 62:54-59.

18. Population projections for Sudan 1993-2018. Khartoum, Sudan Ministry of Finance and National Economy, Central Bureau of Statistics, 1996.

19. Awasthi S. Anemia and undernutrition among preschool children in Uttar Pradesh, India. Indian Pediatrics, 2000, 40:985-990.

20. Chaudhuri K. Anemia and nutritional status of preschool children in Kalara. Indian Pediatrics, 2000, 8:6-7.

21. Bamidele JO et al. Prevalence and determinants of anemia among primary school pupils of a peri-urban community in Osun State, Nigeria. International Journal of Adolescent Medicine and Health, 2010, 22:461-468.

22. Luo R et al. Anaemia among students of rural China's elementary schools: prevalence and correlates in Ningxia and Qinghai's poor counties. Journal of Health, Population, and Nutrition, 2011, 29:471-485.

23. Thane CW, Bates CJ, Prentice A. Risk factors for low iron intake and poor iron status in a national sample of British young people aged 4-18 years. Public Health Nutrition, 2003, 6:485-496.

24. Gwatkin D et al. Socio-economic differences in health, nutrition, and population within developing countries. Washington DC, World Bank, 2007.

25. Oliveira MA, Osório MM, Raposo MC. Socioeconomic and dietary risk factors for anemia in children aged 6 to 59 months. Jornal de Pediatria, 2007, 83:39-46.

26. Variyam JN et al. Mother's nutrition knowledge and children's dietary intakes. American Journal of Agricultural Economics, 1999, 81:373-387.

27. A poverty profile for the Northern States of Sudan. Washington DC, World Bank, Poverty Reduction and Economic Management Unit, African Region, 2011.

28. Haughton J, Khander S. Handbook on poverty and inequality. Washington DC, World Bank, 2009.

29. National baseline household survey2009. Khartoum, Sudan, Central Bureau of Statistics, 2009.

30. Human development report. The rise of the Sudan: human progress in a diverse world. New York, United Nations Development Programme, 2013. 
31. Alawadi A. Nutritional status survey of preschool children in Kuwait. Eastern Mediterranean Health Journal, 1996, 2(3):386-395.

32. Hassan MM. Glucose-6-phosphate dehydrogenase deficiency in the Sudan. Journal of Tropical Medicine and Hygiene, 1971, 74:187-188.
33. Thompson J, Biggs BA, Pasricha SR. Effects of daily iron supplementation in 2- to 5-year-old children: systematic review and meta-analysis. Pediatrics, 2013, 131:739-753. 